\title{
Venture capital investment performance: Based on innovation perspective of multi-factor effect
}

\author{
Yan Jiang ${ }^{1, a}$, Ye $\mathrm{Xu}^{2}$ \\ ${ }^{1}$ Department of Economics, Hong Kong University of Science and Technology, Hong Kong, China \\ ${ }^{2}$ Department of Economics, Hong Kong University of Science and Technology, Hong Kong, China
}

Keywords: foreign venture capital firms, domestic venture capital firms, portfolio company performance, China, multi-factor effect.

\begin{abstract}
China's capital market is booming in recent years. Large numbers of starting-up companies are showing up, which attracts both domestic and foreign venture capital firms. This paper investigates the impact of venture capital investment on the impact of portfolio companies. The innovation and significance of this article lies in: 1) widened the dimension of the VC research: study the multi-factor effect on portfolio companies; 2) expanded the sample size: covering all the manufacturing companies in China that received venture investment between 1999 and 2014. We focus on the impact of foreign VC firms and domestic VC firms on the ROA performance of Chinese portfolio companies by conducting a Least Square Regression. The model shows that portfolio company industry, investment stage as well as capital managed by VC firms is factors significantly affect portfolio company performance. Specifically, we find that after controlling for eight factors, namely, China region, industry, syndicate size, stage indicator, company CEO experience, total venture capital investment, VC firm capital under management, and VC firm age, whether VC firm is domestic or foreign doesn't play an important role.
\end{abstract}

\section{Introduction}

Venture capital (VC), as a form of financial investment has breeded a number of booming companies these days. Companies with high growth potential receive investment at an early stage. And VC firms earn money through owning equity of the invested company. Usually, VC firms finally exit by IPO or trade sale.

${ }^{\mathrm{a}}$ Yan Jiang : jiangyan_316@qq.com 
Venture capital is a relatively new form of investment. It first started in the developed world, with some of the successful examples as Apple, Google, and Facebook. And now it extends to the developing world and has become more important than ever before. Despite the very short history of VC, which only started after World War II, there is an always different view on the definition of VC. The European Private Equity and Venture Capital Association featured venture capital with investment in early stage business seeking higher returns (2005). While the Organization for Operation and Development (1998, OECD) highlights the growth potential of investment business and the value-added contribution of venture capital (Naqi, Hettihewa, 2007). But one thing could be confirmed is that, venture capital is a subset of Private Equity and as its name shows, it bears high risk, and also may generate high profits.

With the fast economic development in Asia, venture capital also experiences comparable growth there. In Asia, it has been growing at $15 \%$ annually in the past 15 years, while the growth rate is only $6 \%$ in Europe and less than 4\% in the United States during the same period (Naqi, Hettihewa, 2007). In the Asia venture capital market, China market is expanding rapidly, although its fast development was only started in 1990s. In China, venture capital was originally deemed as a type of government funding to support new technology. It was not until 1998 that the first corporate-backed firms was established. And a few foreign VC firms also entered China market in the early 1990s (Steveblank, 2013). From then on, China's venture capital entered a fast growing path. Now, the total venture capital investment reaches No.1 in Asia and No. 5 in the world (Wang, Wang, 2011).

In accordance with the fast growing venture capital market, there are a number of researches on this topic. And considering the topic of this study, we are going to reviewing studies relating to foreign and domestic venture capital.

Many studies explore factors affecting the performance of foreign and domestic venture capital. One of the barrier for foreign venture capital to enter the local market is the country difference. $\mathrm{Li}$, Vertinsky and Li (2014) distinguishes such country difference for VC investment as institutional distance (regulatory system, institutionalized practice) and culture distance. Both differences negatively affect investment performance. But as VC firms are more experienced in international investment, the effect from institutional distance is attenuated but that from cultural distance still exists. Dai, Jo and Kassicieh(2012) also confirms cultural distance between foreign VC firms and the local portfolio company as a source of barrier for cross-border investment. Their study shows that such distance not only discourage partnership between the two, but also has a negative impact on the exit performance of the ventures. However, partnership among local VC and foreign VC firms can alleviate such frictions. However, even a portfolio company is invested by a local VC firm, there is still local bias existing. Cumming and Dai (2010) stated in their research that more reputable and more sociable venture capital firms tend to have less local bias. But stage and specification in technology industry increases such bias.

Apart from single venture capital investors, in most cases, portfolio companies receive investment from a few VC firms as a syndicate. Tykvováa and Schertler's (2011) Suggests that strong local ties intensity increases the possibility of foreign investment. Thus such local ties stimulate cross-border venture capital syndication, allowing investors to build geographically diversified portfolio. Besides, syndication also affect VC firms' behavior and performance. A study based on the comparison between US-European syndicate and US VC firms finds out that cross-border Syndicate VC firms usually have larger size and invest more in later stage, thus a higher tendency to express risk. (Espenlaud, Khurshed, Mohamed, 2014).

In addition to country difference, Wang, Wang (2011) investigate how foreign VC's human capital and domestic entrepreneurs' experience affect both $\mathrm{VC}$ investments and portfolio companies. And 
their analysis indicates that there is no significant relationship between foreign VC's human capital and their cross-border performance in China, while domestic entrepreneurs' characteristics has a greater impacts.

Di Guo and Kun Jiang (2014) justifies that, in Chinese VC market, VC firms select firms with better financial performance as well as higher investment in R\&D. Such selection as well as VC firms' participation improve portfolio company performance. However, such improvement is only significant when companies are invested by foreign VC firms, which indicates that foreign VC firms and domestic VC firms play different roles.

Apart from VC firm related factors and portfolio company features, the macro factors of the domestic country also play a role in cross-border VC firms' performance. Wang and Wang's study (2012) indicates that GDP level, stock market performance, legal institution quality as well as domestic country's entrepreneurial activities feature a country's economic freedom. In a more economically free country, foreign VC firms are more likely to exit through IPO or M\&A with shorter duration in Portfolio Company.

After reviewing former studies on factors affecting venture capital performance, this study decides to focus on the how foreign venture capital and domestic venture capital firms affect the portfolio company performance differently.

\section{Data}

\subsection{Data and sample}

Table1: variable definitions

\begin{tabular}{ll}
\hline Variable & Definition \\
\hline ROA & The return on assets of portfolio company in the recent year \\
VC_TYPE & An indicator that equals to one if the portfolio company is backed by foreign \\
& VC firm or the largest one of its syndication is from foreign, and equals to \\
& zero if backed by domestic VC firm and the largest investor is domestic. \\
& An indicator that equals to one if the location city of the portfolio company is \\
in three major urban agglomerations, and equals to zero if otherwise. & An indicator that equals to one if the portfolio company belongs to high-tech \\
REGION & sectors, and equals to zero if otherwise. \\
INDUSTRY & $\begin{array}{l}\text { The natural logarithm of the number of VCs who participated in the portfolio } \\
\text { company's funding. }\end{array}$ \\
NO_INVESTORS & $\begin{array}{l}\text { An indicator that equals to one if the first investment by the VC firm in the } \\
\text { portfolio company occurred at the seed or early stage of development, and }\end{array}$ \\
STAGE_INDICATOR & equals to zero if at the growth or late stage. \\
An indicator that equals to one if the portfolio company executives have \\
previously served as top managers at the time of her joining the portfolio \\
company as CEO, and equals to zero if no any experience.
\end{tabular}

The aim of this study is to examine whether Foreign Venture Capital Firm(FVCF) and Domestic Venture Capital Firm(DVCF)have significant different impact on portfolio company's performance. We obtain data from SDC VentureXpert database. This database is a primary data source for VC deals worldwide, with over 45 years of historical data. 
Initially, we extract a list of 2465 VC-backed companies receiving their first venture capital investment prior to January 2015 from the VentureXpert database. We exclude VC investments which are not disclosed with full information and we are then left with 342 VC-backed companies. This sample represents all the manufacturing companies in China that received venture investment between 1999 and 2014. Among the 342 VC investments, each observation is a portfolio company and each VC firm-portfolio company pair is unique. We model the performance measure variable and explained variable, and obtain the VC firm-level and portfolio company-level control variables. Table 1 summarizes the variables.

\subsection{Variables}

\subsubsection{Performance measure}

The performance of portfolio company is the dependent variable in this study. We estimate the performance in profitability dimension. Profitability is measured by the return on assets $(R O A)$. We obtain the net income and total assets number of portfolio companies from the Venturexpert database and then calculate the ROA by dividing the net income by total assets. The return on assets (ROA) shows the percentage of how profitable a company's assets are in generating revenue and also is one of the elements used in financial analysis using the Du Pont Identity. As the core index of reflecting the comprehensive utilization of enterprise assets efficiency, we use ROA as the important indicator of the enterprise total assets profitability. The higher the return on assets, the stronger the portfolio company creates profit.

\subsubsection{Independent variable}

We are interested in the changes in performance of portfolio companies in relation to the venture capital firm type(FVCF and DVCF) within the examination period. Hence, we need a variable to distinguish whether the firm is backed by Foreign Venture Capital Firm(FVCF) or Domestic Venture Capital Firm(DVCF). The VC type Dummy variable is equal to 1 if the firm is backed by foreign VC firm or the largest one of its syndication is from foreign, and equals to zero if backed by domestic VC firm and the largest investor is domestic.

\subsubsection{Control variables}

Eight control variables are included in the analysis, namely, China region, industry, syndicate size, stage indicator, company CEO experience, total venture capital investment, VC firm capital under management, and $\mathrm{VC}$ firm age.

China currently has formed three major urban agglomeration, namely, the Pearl River Delta Urban Agglomeration and Yangtze River Delta Urban Agglomeration, the Beijing-Tianjin-Hebei urban agglomeration. They are the most dynamic and main force of China's economics development. Companies which are located in the three major urban agglomeration are likely to have the resource advantages no matter in raw materials or human capital. Thus, those companies can benefit from the geographical location. The China region dummy variable is equal to 1 if the portfolio company is located in Beijing-Tianjin-Hebei region, Yangtze River Delta, and Pearl River Delta, and equal to 0 if not.

As in the China VC market, the majority of Chinese portfolio companies belong to high-tech sectors. Thus, we need to control for the industry dummy variable which is equal to 1 if the portfolio company is classified as high-tech industry, and equal to 0 if not.

The syndicate size is measured by the natural logarithm of the number of VCs who participated in the portfolio company's funding. Espenlaud, Khurshed and Mohamed's study (2014) indicates crossborder syndicate VC firms have larger size and more investment in later stage, thus each of the VC firms bears smaller risk. Syndication also prevents competition among investors (Casamatta and Haritchabalet, 2007). 
We control for the stage indicator variable indicating whether the first $\mathrm{VC}$ investment in a portfolio company occurs at the seed/early stage of development. Companies in the early stages of developments are likely to be riskier and this may affect portfolio company's performance.

Human capital plays an important role in the governance and operation of the portfolio company. CEO experience, as a key factor on company's human capital, is equal to 1 if the CEO had previously served as a top manager, such as CEO, COO, CTO, CFO etc. and equal to 0 if otherwise.

The total venture capital investment is measured by the natural logarithm of the total VC investment in the portfolio company. VC firms obviously tend to invest in those portfolio companies with better performance. The better the portfolio company is, the more the $\mathrm{VC}$ investors come to them and then the greater total $\mathrm{VC}$ investment the portfolio company obtained. We use the total VC investment in the portfolio company across all financing rounds as one signal of the company productivity.

The VC firm capital under management is measured by the natural logarithm of the VC firm capital under management.

The VC firm age is measured by the years between the VC firm founding year and 2015.

Large capital amount under management and long company history indicate the VC firms' advantages over resources and management power. By involving in the portfolio company's operation management, $\mathrm{VC}$ firms can bring their advantages and experience to the portfolio companies and then improve the portfolio company's performance.

\subsection{Models and methodology}

We aim to test whether portfolio company performance follows different patterns in foreign VC firmbacked company or domestic VC firm-backed company. We measure the impact of VC investments on company's performance with the return on assets (ROA).

Regarding the dependent variables and independent variables explained above, our model is represented as follows:

Return on total assets(ROA) $=F(\mathrm{VC}$ type, Region, Industry, No. of investors, Stage indicator, Company CEO Experience, Total VC investment, VC capital size, VC age)

Regarding the estimation process, our data refer to latest ROA series observations on a number of portfolio companies which disclosed with full information in VentureXpert database, with some independent variables being time invariant. Accordingly, LS regression is performed to estimate the model.

\subsection{Descriptive statistics}

Table2 presents the distributions of our sample. The number of observations and the corresponding percentages (in parentheses) are listed. Panel A presents the distribution of VC-backed companies by industry and Chinese region. According to the seven geographic partition in China, we classify the locations of portfolio companies into seven major regions in China which are east, north, south, central, south-west, north-east and north-west. As shown, most portfolio companies are located in east and north, with almost $39 \%$ and $26 \%$ of the sample respectively. The industry classification in SDC VentureXpert database just includes three categories: Information Technology, Medical/Health/Life Science, and Non-High Technology. Since the non-high technology category concludes the remaining industries, we can find that the Chinese portfolio companies in high-tech sectors are much more preferred by VC firms than companies in other industries.

Such phenomenon can be explained by the fact that in China, technicians are usually those with ideas and technical but lack of capital and management skills. However, in order to transfer technology and ideas into products and generate profits requires all these essentials. Besides, considering the high-risk feature of high-tech start-up companies as well as the fast development 
nature of this industry, it is rather difficult to get financed through normal channel such as bank loan, issuing stocks or bonds. Venture capital perfectly solve all these problems.

Panel B presents the distribution of VC-backed companies by industry and development stage. As shown, most VC investments are made at growth stage and late stage no matter what industry.

Panel $\mathrm{C}$ presents the distribution of VCs by type and firm capital under management. As shown, during the last 16 years most $\mathrm{VC}$ investment in Chinese portfolio companies are made by domestic VC firms which account for $74 \%$. Most firm capital under management of domestic VC firms are under $\$ 500$ million and most firm capital under management of foreign VC firms are above $\$ 500$ million.

Table2: Sample descriptions. The sample consists of 342 VC-backed companies that received their initially investment during 1999-2014 and for which data is available in the database. The tables present the distribution of VC-backed companies by industry and Chinese region in panel A, the distribution of VC-backed companies by industry and development stage in panel $\mathrm{B}$, and the distribution of VCs by type and firm capital under management in panel C. Each panel presents the number of observations and the corresponding percentage (in parentheses).

Panel A: distribution of VC-backed companies by industry and Chinese region

\begin{tabular}{|c|c|c|c|c|c|c|c|c|}
\hline China region & East & North & South & Central & $\begin{array}{l}\text { South- } \\
\text { west }\end{array}$ & $\begin{array}{l}\text { North- } \\
\text { east }\end{array}$ & $\begin{array}{l}\text { North- } \\
\text { west }\end{array}$ & total \\
\hline \multicolumn{9}{|l|}{ Company Industry Class } \\
\hline Non-High Technology & $84(24.56)$ & 41(11.99) & $26(7.60)$ & $18(5.26)$ & $6(1.75)$ & $8(2.34)$ & $7(2.05)$ & $190(55.56)$ \\
\hline $\begin{array}{l}\text { Information } \\
\text { Technology }\end{array}$ & 41(11.99) & $45(13.16)$ & $30(8.77)$ & $3(0.88)$ & $8(2.34)$ & $2(0.58)$ & $0(0)$ & $129(37.72)$ \\
\hline $\begin{array}{l}\text { Medical/Health/Life } \\
\text { Science }\end{array}$ & $8(2.34)$ & $3(0.88)$ & $6(1.75)$ & $3(0.88)$ & $3(0.88)$ & $0(0)$ & $0(0)$ & $23(6.73)$ \\
\hline total & 133(38.89) & $89(26.02)$ & $62(18.1)$ & $24(7.02)$ & $17(4.97)$ & $10(2.92)$ & $7(2.05)$ & $342(100)$ \\
\hline
\end{tabular}

Panel B: distribution of VC-backed companies by industry and development stage

\begin{tabular}{lllll}
\hline Development stage & Seed/early stage & Growth stage & Late stage & total \\
\hline Company Industry Class & & & & \\
\hline Non-High Technology & $21(6.14)$ & $64(18.71)$ & $105(30.70)$ & $190(55.56)$ \\
\hline Information Technology & $24(7.02)$ & $55(16.08)$ & $50(14.62)$ & $129(37.72)$ \\
\hline Medical/Health/Life Science & $4(1.17)$ & $11(3.22)$ & $8(2.34)$ & $23(6.73)$ \\
\hline total & $49(14.33)$ & $130(38.01)$ & $163(47.66)$ & $342(100)$ \\
\hline
\end{tabular}

Panel C: distribution of VCs by type and firm capital under management

Firm Capital under Management above 500 million \$ under 500 million \$ total

\begin{tabular}{llll}
\hline VC type & & & \\
\hline DVCF & $84(24.56)$ & $169(49.42)$ & $253(73.98)$ \\
\hline FVCF & $78(22.81)$ & $11(3.22)$ & $89(26.02)$ \\
\hline total & $162(47.37 \%)$ & $180(52.63)$ & $342(100)$ \\
\hline
\end{tabular}

Table3 provides the descriptive statistics of the VC-backed companies, including means, minimums, maximums, and standard deviations of financial statistics for the VC-backed companies. As shown, the ROA, net income, and total assets are significantly different in FVCF-backed and DVCF-backed 
companies, with the later one having a larger number of ROA on average and but having a lower level of net income and total assets.

Table3: Descriptive statistics of VC-backed companies:

Panel A: FVCF-backed companies

\begin{tabular}{llllll}
\hline variables & obs & mean & std. & $\min$ & $\max$ \\
\hline ROA & 89 & 0.056731 & 0.202531 & -0.640678 & 0.602393 \\
\hline net income $(\$ 000)$ & 89 & 71,156 & 349,831 & $(1,006,700)$ & $2,289,951$ \\
\hline total assets $(\$ 000)$ & 89 & $1,059,145$ & $3,431,958$ & 9,820 & $24,537,555$ \\
\hline
\end{tabular}

Pane B: DVCF-backed companies

\begin{tabular}{llllll}
\hline Variables & obs & mean & std. & $\min$ & $\max$ \\
\hline ROA & 253 & 0.108347 & 0.139054 & -1.376342 & 0.765458 \\
\hline net income $(\$ 000)$ & 253 & 31,764 & 132,075 & $(94,293)$ & $1,469,728$ \\
\hline total assets $(\$ 000)$ & 253 & 658,052 & $4,546,542$ & 2,441 & $69,311,281$
\end{tabular}

\subsection{Results}

Table 4 reports the regression results of the LS model on ROA of portfolio companies, VC type variable and other control variables. As shown, the coefficient of VC type dummy variable is not significant and only the coefficients on industry, stage indicator and total VC investment variables are significant.

Table 4: the regression results of the LS model on ROA of portfolio companies, VC type variable and other control variables; The significance levels at $1 \%, 5 \%$ and $10 \%$ are identified by $* * *, * *$ and $*$, respectively

\begin{tabular}{lllll}
\hline \hline Variable & Coefficient & Std. Error & t-Statistic & Prob. \\
\hline CONSTANT & $0.320311^{* * *}$ & 0.061336 & 5.222238 & 0.0000 \\
\hline VC_TYPE & 0.002205 & 0.026066 & 0.084588 & 0.9326 \\
\hline REGION & -0.007443 & 0.018750 & -0.396968 & 0.6916 \\
\hline INDUSTRY & $-0.031759^{*}$ & 0.017967 & -1.767645 & 0.0780 \\
\hline NO_INVESTORS & -0.004887 & 0.003662 & -1.334354 & 0.1830 \\
\hline STAGE_INDICATOR & $-0.079697 * * *$ & 0.024348 & -3.273311 & 0.0012 \\
\hline CEO_EXPERIENCE & -0.003674 & 0.024898 & -0.147553 & 0.8828 \\
\hline TOTAL_VC_INVESTMENT & $-0.019925^{* * *}$ & 0.006478 & -3.075763 & 0.0023 \\
\hline VC_CAPITAL_UNDER_MGMT & 0.004058 & 0.004651 & 0.872606 & 0.3835 \\
\hline VC_AGE & -0.000680 & 0.000737 & -0.922559 & 0.3569 \\
\hline
\end{tabular}

The F-statistic test shows that the LS model is significant and the Durbin-Watson test shows that there is no autocorrelation in the residuals from the LS model. Moreover, to ensure no omitted variables in LS model, we apply the Ramsey Regression Equation Specification Error Test (RESET) test(shown in table5) on this model. And, the test results show that the null-hypothesis that there are omitted variables in the model is rejected, which means the LS model is acceptable. 
Table5: Ramsey Regression Equation Specification Error Test (RESET) test results showed that Prob.F is far above from the significant level $1 \%$, which indicated that the null-hypothesis that there are omitted variables in the model is rejected.

Ramsey RESET Test:

\begin{tabular}{llll}
\hline \hline F-statistic & 0.209004 & Prob. F(1,331) & 0.6478 \\
Log likelihood ratio & 0.215881 & Prob. Chi-Square(1) & 0.6422 \\
\hline \hline
\end{tabular}

Test Equation:

Dependent Variable: ROA

Method: Least Squares

\begin{tabular}{lllll}
\hline \hline Variable & Coefficient & Std. Error & t-Statistic & Prob. \\
\hline \hline VC_TYPE & 0.002955 & 0.026149 & 0.113001 & 0.9101 \\
REGION & -0.008748 & 0.018988 & -0.460726 & 0.6453 \\
INDUSTRY & -0.037335 & 0.021733 & -1.717877 & 0.0868 \\
NO_INVESTORS & -0.005043 & 0.003683 & -1.369357 & 0.1718 \\
STAGE_INDICATOR & -0.087513 & 0.029774 & -2.939253 & 0.0035 \\
CEO_EXPERIENCE & -0.004267 & 0.024962 & -0.170953 & 0.8644 \\
TOTAL_VC_INVESTMENT & -0.023462 & 0.010095 & -2.324035 & 0.0207 \\
VC_CAPITAL_UNDER_MGMT & 0.004777 & 0.004915 & 0.972028 & 0.3317 \\
VC_AGE & -0.000751 & 0.000754 & -0.996171 & 0.3199 \\
CONSTANT & 0.366695 & 0.118596 & 3.091957 & 0.0022 \\
FITTED^2 & -0.906913 & 1.983758 & -0.457169 & 0.6478 \\
\hline \hline
\end{tabular}

\section{Analysis}

In this part, we analyze the impact of each variable on portfolio company performance according to the result of Least Square Regression.

\subsection{The impact of VC type}

As shown in table 4, the coefficient of VC type is 0.002205 , but with no significance, which shows that whether it is a foreign VC firm or a domestic VC firm doesn't affect portfolio company performance significantly. This result is different from what most studies get on the impact of foreign and domestic VC firms' different impact on portfolio companies. Most studies show that country difference in regulatory system, institutional practices as well as culture act as a barrier for foreign VC firms to enter the local market. Besides, even though they do enter the market, their performance is negatively affected by such differences. However we should notice that most studies are either focused on Global market or Asia market. The Chinese market has its specialty on the issue of foreign $\mathrm{VC}$ investment.

In the past decades, China has been on its fast growing path, with large numbers of Small and Medium Enterprises (SMEs). These SMEs are either featured with high-technology, or new business model. As Chinese has limited knowledge about venture capital investment at that time, and its Growth Enterprise Market was still on its way, it was difficult for these SMEs to raise enough money for development. On the other hand, NASDAQ in the U.S. and other similar foreign Growth Enterprise Market was recovering. Foreign VC firms from these countries sensed such opportunities in China market, thus set up institutions in China and focused on investing Chinese high-tech SMEs (Wang, 2009). Based on its history and experience in venture capital investment compared to local 
venture capital firms, these foreign VCs actually gained an advantage over those local VC firms. Successful examples includes Sohu and Ctrip, which both went IPO in NASDAQ. Due to such gap between Chinese and foreign VC firms, the negative effect from country difference is in deeded made up by other factors such as experience, and thus results in the insignificance of the variable in the regression model. Besides, we also notice that the coefficient of $\mathrm{VC}$ firm type is positive, which also corresponds to the analysis that foreign VC firms perform better than domestic VC firms.

However, considering recent development of Chinese capital market along with more regulations on foreign venture capital investment, such country difference mentioned early should be taken into consideration, which may result in a disadvantage for foreign VC firms. Besides, since foreign VC firms make more investment in Portfolio Company's early stage according to our sample, it implies that they may have to bear larger risk compared to local firms.

\subsection{The impact of portfolio company region}

The outcome of regression indicates that portfolio company region isn't a significant factor that affects their performance. When VC firms are looking for possible portfolio companies, they would take consideration of its economic environment, including human capital, transportation, supporting facilities, etc. Despite of these factors, the distance between VC firms and portfolio firms also affects the possibility of investment. Because closer investment enables VC firms to have more participation into the company's management and increase the possibility of success. But in our example, even those portfolio companies are not in the most developed regions in China, they are still mostly located in big cities such as Chengdu, Wuhan Xi'an, which are key cities of middle and western areas of China. These key cities are attached with great importance for the development of Western China and receive support from the central government. As a result, the region factor doesn't play a significant part in China market.

On the other hand, we should pay attention that the portfolio company cluster is an obvious trend in China. Nearly $40 \%$ of portfolio companies are in Eastern China. This part of China is featured with more universities and an open environment for innovation, which has already become a breeding ground for China's innovation enterprises. Even though there is no significance for the region factor in portfolio company performance, it is a better choice for VC firms to choose companies located in these regions.

\subsection{The impact of portfolio company industry}

As is shown in table 4, the industry of portfolio company has significant influence on its performance with a coefficient of -0.031759 . The negative sign indicates that high-tech portfolio companies has a lower ROA than non-tech companies. These result can be explained at least by the following reasons. First, most Chinese start-up companies are doing business in high-tech industry at current stage. As a result, large numbers of new entrants into the market makes the competition really fierce. Besides, high-tech industry is featured with fast-updating, thus outdated products are quickly of little value, which makes gaining profits even harder. Last but not least, ROA reflects the profitability of both shareholder and creditor. Companies' ROA level could vary at a wide range according to different leverage level.

Considering the significance of industry to portfolio company performance, we may consider whether VC firms should attach more emphasis on non-tech firms. Although most of the successful venture capital investment cases are in high-tech firms, the model result indicates that investing in non-tech firms can result in better return to some extent.

\subsection{The impact of number of investors}

The regression model shows that the number of venture capital firms is not a significant factor affecting portfolio company performance. This result is different from previous studies. Espenlaud, 
Khurshed and Mohamed's study (2014) indicates cross-border syndicate VC firms have larger size and more investment in later stage, thus each of the VC firms bears smaller risk. Syndication also prevents competition among investors (Casamatta and Haritchabalet, 2007). But the result in our model shows that the more investors or larger syndicate size doesn't make contribution to portfolio performance significantly. Although syndication has the benefit of experience from different VC firms, such as foreign VC's investment experience as well as domestic VC's closer culture tie with portfolio companies, there are also disadvantages such as inner disagreement among VC firms, communication cost and investment philosophy difference. VC firms usually play an active role in the management of portfolio companies in order to achieve their better performance. Thus, more VC firm engagement means higher cost for communication and coordination. And the performance of portfolio companies can be negatively affected. For example, foreign VC firms usually have more choice for exit because of the more development of their capital market. Except for IPO, they often sell part of the shares in the portfolio company. But for domestic VC firms, they regard IPO as the best exit way. The difference in practice can cause conflicts in the syndicate. Based on such reasons, the number of investors can have both positive and negative impact on portfolio company performance, which result in the insignificance of number of investor variable.

\subsection{The impact of development stage of the portfolio company}

As shown in table 4, the stage indicator of the portfolio company has significant influence on its ROA performance with a negative coefficient of -0.079697 . The negative sign indicates that portfolio companies which received the initial VC investment in the early stages of development perform better than those in the growth or late stages. In China, companies meet different problems in early stage, represented by the cash flow issues, adjustment of business model, construction of marketing channels and so on. According to the survey, there are nearly $22 \%$ companies exit or broke in the early stage. The business model, financial management, and R\&D activities of portfolio company are fragile, incomplete and immature. Therefore, companies in the early stages of development are likely to be riskier and this may affect company performance. It can also explain the statistic result shown in Panel $\mathrm{B}$ of table 2 that most VC firms prefer to enter the VC fund rounds in portfolio companies in growth or late stage rather than early stage.

\subsection{The impact of company CEO experience}

The regression model shows that the CEO experience is not a significant factor affecting portfolio company performance. Many research concerning whether executives' previous experience impacted the Chinese company profitability performance have been conducted. Based on the literature review, Chinese companies still prefer CEO's individual decision. However, executives with rich working experience value his intuition and perception during strategy formation, which may result in cognitive bias and negative influence to the companies. It is undeniable that with rich working experience, executives would be more skilled when faced with business dilemma, and improve effectiveness. Their excellent leadership and wide network also benefit its business. Considering both effect discussed above, the two sides of executive performance offset and make the general effect insignificant.

\subsection{The impact of total venture capital investment in the company}

As shown in table 4, total VC investment has significant influence on its ROA performance with a negative coefficient of -0.019925 . The negative sign indicates that with greater VC investment, the portfolio company perform worse. The result may violate previous cognition that greater total VC investment, which indicates more investors are beneficial to this portfolio company. The reason of such contradiction is likely to be associated with better portfolio company quality. Firstly, large amount of VC investment usually come form large VC syndicate. And, we have explained in 3.4 that 
the higher communication cost and more conflicts from more investors in the financing rounds lower portfolio company performance. Secondly, asymmetric information and adverse selection may make it harder for VC investors to figure out companies' real quality. Thirdly, the more fund VC firm invest in portfolio company, the more likely $\mathrm{VC}$ firm tends to increase its power in operation management and try to control the business, which may instead, result in larger cultural distance and conflicts during management; thus, its interference actually negatively affect the portfolio company performance.

\subsection{VC firm: total capital under management and firm age}

We control for total capital under management and VC firm age. The result shows these two factors doesn't impact the portfolio company's performance significantly. Large capital amount under management and long company history indicate company strength. And the regression result tells that VC firm actually doesn't improve portfolio company performance that much. One possible explanation is that the VC firms offer financial support only and doesn't get involved the company governance. Moreover, even if the participate in the operation management, the cultural distance between VC firm and portfolio company can still leads to ineffectiveness. Besides, individual dictatorship is common in Chinese companies and local entrepreneurs regard VC investment only as obtaining enough fund support rather than management participation. Therefore, under this cultural background, VC firm characteristic doesn't impact the portfolio company significantly.

\section{Conclusion}

According to the analysis above, we get to the conclusion that there do exist some factors affecting the performance of portfolio firms. Such factors includes features of portfolio firms such as industry, stage they receive investment, as well as features of VC firms, such as capital under management. However, whether VC firms are domestic or foreign doesn't make too much difference to portfolio firm's performance. The Chinese capital market's fast development and its changing feature makes the result in this model quite different from previous studies.

\section{Limitation}

Since the sample is acquired from VentureXpert data base, and all the observations in the study are those with complete information, it probably has the problem of survivorship bias. Portfolio companies with full information are mostly those who perform well. As a result, upward bias may arise. Besides, the sample covers quite a wide range, from 1999 to 2014, during which time, China's Capital market develops at a fantastic speed. As a result, the model may not be able to reflect the recent trend of Chinese venture capital investment.

\section{Acknowledgement}

We wish to thank Dr. Susheng Wang, Professor of department of economics, Hong Kong University of Science and Technology. He gave full support to us from research topic to data collection. Both authors acknowledge the refereeing support from Professor Wang. The authors assume responsibility for any error. 


\section{References}

1. Annalisa Croce, Jose Marti, Samuele Murtinu. The impact of venture capital on the productivity growth of Europeean entreprenurial firms: "Screening" or "value added" effect?[J]. Journal of Business Ventureing, 2013, 28: 489-510.

2. Casamatta, C., Haritchabalet, C. Experience, screening and syndication in venture capital investments[J]. Journal of Financial Intermediation, 2007, 16(3): 368

3. Di Guo, Kun Jiang. Venture capital investment and the performance of entrepreneurial firms: Evidence from China[J]. Journal of Corporate Finance, 2013, 22, 375-395.

4. Douglas Cumming, Na Dai. Local bias in venture capital investments[J]. Journal of Empirical Finance, 2010, 17: 362-380.

5. Jose Marti, Susana Menendez-Requejo, Olaf M. Rottke. The impact of venture capital on family business: Evidence from Spain[J]. Journal of World Business,2013, 48: 420-430.

6. Lanfang Wang, Susheng Whang. Cross-border venture capital performance: Evidence from China[J]. Pacific Basin Financial Journal, 2011, 19: 71-97.

7 Lanfang Wang, Susheng Wang. Economic freedom and cross-border venture capital performance[J]. Journal of Empirical Finance, 2012, 19: 26-50.

8. Mark Humphery-Jenner, Jo-Ann Suchard. Foreign VCs and venture success: Evidence from China[J]. Journal of Corporate Finance, 2013, 21: 16-35.

9. Na Dai, Hoje Jo, Sul Kassicieh. Cross-border venture capital investments in Asia: Selection and exit performance[J]. Journal of Business Venturing, 2012, 27: 666-684.

10. Sayed Ahmed Naqi, Samanthala Hettihewa. Venture capital of Private equity? The Asia experience[J]. Business Horizons, 2007, 50: 335-344.

11. Susanne Espenlaub, Arif Khurshed, Abdulkadir Mohamed. Does cross-border syndication affect venture capital risk and return[J]. International Review of Financial Analysis, 2014, 31: 13-24.

12. Tereza Tykvováa, Andrea Schertler. Cross-border venture capital flows and local ties: Evidence from developed countries[J]. The Quarterly Review of Economics and Finance, 2011, 51, 36-48.

13. Yong Li, Ilan B. Vertinsky, Jing Li. National distances, international experience, and venture capital investment performance[J]. Journal of Business Venturing, 2014, 29: 471-489. 